\title{
Pengaruh Letak Buah pada Berbagai Umur Tanaman Terhadap Mutu Kakao (Theobroma cacao L.)
}

\section{Effect of Fruit Position on Plants of Various Ages to the Quality of Cocoa (Theobroma cacao L.)}

\author{
Asrianingsi ${ }^{1}$, Sarawa Mamma ${ }^{2 *}$, Dirvamena Boer $^{2}$ \\ 1) Alumni Program Studi Agronomi Program Pascasarjana UHO \\ ${ }^{2)}$ Dosen Program Studi Agronomi Program Pascasarjana UHO
}

Diterima: 10 Maret 2017/Disetujui: 2 Maret 2018

\begin{abstract}
ABSTRAK
Penelitian ini bertujuan untuk mengetahui pengaruh letak buah dan perbedaan umur tanaman terhadap mutu kakao. Penelitian ini dilaksanakan pada bulan Juni tahun 2015. Pengambilan sampel dilakukan di lahan petani kakao di Kecamatan Wonggeduku Kabupaten Konawe. Penelitian dilakukan pada tanaman kakao jenis hibrida (Trinitario) warna hijau umur 8, 10, 12 dan 14 tahun. Rancangan percobaan yang digunakan adalah rancangan tersarang dengan pola RAL dengan 3 ulangan. Umur tanaman yaitu umur 8, 10, 12 dan 14 tahun; serta umur letak buah tersarang pada umur tanaman meliputi batang, cabang primer dan cabang sekunder. Setiap plot terdiri dari 3 unit percobaan dan setiap unit percobaan terdiri dari 3 tanaman sehingga jumlah tanaman menjadi 36 tanaman kakao dan 108 buah kakao. Data hasil pengamatan dianalisis menggunakan analisis ragam dan hasil analisis yang menunjukkan pengaruh nyata dilanjutkan dengan Uji Jarak Berganda Duncan taraf 5\%. Hasil penelitian menunjukkan bahwa letak buah kakao berpengaruh sangat nyata terhadap semua variabel penelitian kecuali pada variabel berat buah yang berpengaruh tidak nyata. Hasil penelitian juga menunjukkan bahwa semakin tua tanaman kakao maka semakin menurun mutu kakaonya. Umur tanaman kakao terbaik terhadap mutu kakao diperoleh pada umur 8 tahun.
\end{abstract}

Kata kunci: Kakao, kualitas biji, letak buah, umur tanaman

\section{ABSTRACT}

This study aims to determine the effect of the location of the fruit and the difference in age of the plant to the quality of cocoa. This research was conducted in June 2015. Sampling was carried out on cocoa farmer land in Wonggeduku Subdistrict, Konawe Regency. The study was conducted on green hybrids (Trinitario). The experimental design used was a nested design with RAL pattern with 3 replications. Plant age is 8, 10, 12 and 14 years old; and the age of the nesting fruit at the age of the plant include the stem, primary branch and secondary branch. Each plot consists of 3 experimental units and each experimental unit consists of 3 plants so that the number of plants were 36 cocoa plants and 108 cocoa fruits. The data was analized by using Duncan's Multiple Range Test. The results showed that the location of cacao fruit had a very significant effect on all research variables except for fruit weight variables which had no significant effect. The results of the study also showed that the older the cocoa plant, the lower the quality of cocoa. The age of the best cocoa plants on the quality of cocoa is obtained at the age of 8 years.

Keywords: Cocoa, fruit location, plant age, seed quality.

\footnotetext{
*Penulis untuk korespondensi. Email e-mail: $\underline{\text { sarawa60@yahoo.com }}$
} 


\section{PENDAHULUAN}

Kakao merupakan salah satu komoditas andalan perkebunan yang peranannya cukup penting bagi perekonomian nasional, khususnya sebagai penyedia lapangan kerja bagi sekitar 900 ribu kepala keluarga petani, sumber pendapatan dan devisa negara. Kakao juga berperan dalam mendorong pengembangan wilayah dan pengembangan agroindustri (Departemen Perindustrian, 2007).

Cokelat dihasilkan dari biji buah kakao yang telah mengalami serangkaian proses pengolahan sehingga bentuk dan aromanya seperti yang terdapat di pasaran. Biji buah kakao yang telah difermentasi dijadikan serbuk yang disebut cokelat bubuk. Cokelat dalam bentuk bubuk ini banyak dipakai sebagai bahan untuk membuat berbagai macam produk makanan dan minuman, seperti susu, selai, roti dan lain-lain.

Kusumaningrum et al. (2014), mengemukakan bahwa saat ini Indonesia menjadi negara pengekspor biji kakao terbesar ketiga di dunia setelah Pantai Gading dan Ghana, dengan produksi per tahun mencapai 530 ribu ton, yang setara dengan 13,6\% produksi dunia. Konsumsi kakao terbesar dunia adalah Eropa (EU 37\% dan di luar EU 10\%), Amerika (Amerika Utara 24\% dan Amerika Latin 10\%), Asia dan Oceania (10\%), dan Afrika (4\%). Konsumsi perkapita (kg kapita ${ }^{-1} \mathrm{thn}^{-1}$ ) terbesar adalah Switzerland sebesar 5,74; Belgia 5,56; Jerman 4,03; UK 3,52; Perancis 3,43; Amerika 2,45; Rusia 1,43; Jepang 1,25; Brazil 1,03; Ghana 0,55; Pantai Gading 0,48; Nigeria 0,12; Indonesia 0,08; China 0,04 dan India 0,04 (Lokakarya Kakao Indonesia, 2013).

Konawe adalah salah satu wilayah penghasil kakao. Berdasarkan data Dinas Perkebunan Kabupaten Konawe (2013) dalam Konawe dalam Angka (2014) menyebutkan bahwa produktivitas kakao di Kabupaten Konawe pada tahun 2013 mencapai 0,64 ton ha $^{-1}$. Produktivitas tanaman tersebut bersifat fluktuatif dalam kurun waktu 4 tahun mulai dari tahun 2010-2013. Namun, kebutuhan konsumen terhadap biji kakao baik nasional maupun internasional dari tahun ke tahun semakin meningkat, khususnya industri lemak dan makanan cokelat. Pihak industri menerapkan persyaratan mutu yang ketat agar produk cokelat yang dihasilkan aman dikonsumsi dan disukai konsumen. Penelitian tentang bubuk kakao telah pula dilakukan yaitu pencampuran antara bubuk kakao dengan bubuk kedelai sebagai minuman cokelat (Langkong et al. 2011).

Supriatna (2004), mengemukakan bahwa tanaman kakao mencapai produksi puncak pada umur 4-5 tahun dan dapat bertahan selama 20 tahun atau lebih jika pengelolaannya baik. Terdapat dua musim panen dalam satu tahun yaitu panen raya dan panen biasa. Hasil panen raya jauh lebih banyak dibandingkan panen biasa yaitu $>60 \%$ dari total hasil panen setahun. Pada daerah yang memiliki dua musim yaitu musim kemarau dan musim penghujan, panen raya jatuh pada Bulan April hingga Bulan Mei atau setelah masa pembungaan musim hujan selama 5,5 bulan (di dataran rendah) atau 6 bulan (di dataran tinggi). Periode panen umumnya dilakukan antara 7-14 hari sekali tergantung pada jumlah buah yang masak.

Produktivitas tanaman kakao akan menurun seiring dengan bertambahnya umur tanaman yakni setelah mencapai umur 15 tahun. Hal ini dapat diatasi melalui peremajaan atau rehabilitasi tanaman melalui tehnik sambung samping pada awal musim hujan. Tanaman kakao yang disambung samping adalah tanaman yang masih produktif yaitu umur < 15 tahun (Fahmi, 2011). Ernah (2010) mengemukakan bahwa saat optimum peremajaan tanaman kakao terjadi pada umur tanaman 44 tahun.

Biji kakao mengandung berbagai macam komponen kimia, zat gizi dan senyawa bioaktif di dalamnya. Komposisi kimia ini bervariasi setelah mengalami proses pengolahan menjadi produk. Komposisi kimia bubuk kakao berbeda dengan mentega kakao dan pasta coklat. Komposisi kimia bubuk kakao (natural) per 100 gram adalah mengandung kalori 228, $49 \mathrm{Kkal}$; lemak 53,35 g; karbohidrat $13,5 \mathrm{~g}$; serat $27,90 \mathrm{~g}$; protein $19,59 \mathrm{~g}$; air 2,58 g dan kadar abu 6,33; yang meliputi: kalium $1495,5 \mathrm{mg}$; natrium $8,99 \mathrm{mg}$; kalsium $169,45 \mathrm{mg}$; besi 13,86 mg; seng 7,93 mg; tembaga 4,61 mg dan mangan $4,73 \mathrm{mg}$. Komponen senyawa bioaktif dalam bubuk kakao adalah senyawa polifenol yang berfungsi sebagai antioksidan (Jurniati, 2013).

Penelitian Jurniati (2013), menunjukkan bahwa berat daging buah kakao pada batang ratarata $407,311 \mathrm{~g}^{\text {buah }}{ }^{-1}$ dan buah pada cabang ratarata $383,873 \mathrm{~g}_{\text {buah }^{-1}}$. Berat plasenta buah pada batang 15,662 $\mathrm{g}^{\text {buah }^{-1}}$ dan buah pada cabang ratarata $13,902 \mathrm{~g} \mathrm{buah}^{-1}$. Berat biji dengan pulp buah pada batang rata-rata 93,893 dan buah pada cabang rata-rata 87,377 . Berat biji tanpa pulp buah pada batang rata-rata $66,371 \mathrm{~g}^{b^{2}} \mathrm{buh}^{-1}$ dan buah pada cabang rata-rata $62,187 \mathrm{~g}_{\text {buah }^{-1}}$. Jumlah biji per buah pada batang rata-rata 42,0 biji buah $^{-1}$ dan pada cabang rata-rata 40,5 biji buah $^{-1}$. Kadar air biji pada batang rata-rata $6,42 \%$ dan pada cabang $6,39 \%$. Berdasarkan data tersebut, dapat diketahui secara jelas bahwa buah pada batang lebih besar dan lebih berat daripada buah pada cabang. Hal ini disebabkan karena persaingan untuk memperoleh makanan pada cabang lebih besar dibanding 
persaingan untuk mendapat makanan pada batang. Oleh karena itu, perlu dilakukan penelitian terhadap karakteristik biji buah kakao sehingga kita dapat mengetahui bagian pohon yang mana yang dapat menghasilkan biji kakao dengan kualitas terbaik pada berbagai umur tanaman.

Tujuan yang ingin dicapai pada penelitian ini yaitu untuk mengetahui pengaruh perbedaan letak buah dan umur tanaman kakao terhadap kualitas fisik biji kakao.

\section{METODE PENELITIAN}

Penelitian ini dilaksanakan pada Bulan Juni tahun 2015. Pengambilan sampel dilakukan di lahan petani kakao di Kecamatan Wonggeduku Kabupaten Konawe.

Bahan yang digunakan adalah buah kakao masak fisiologis jenis hibrida (Trinitario) warna hijau umur 8, 10, 12 dan 14 tahun. Bahan kimia, yaitu : Hexan, Na.K.Tartar, $\mathrm{NaOH}, \mathrm{CuSO}_{4}, \mathrm{BSA}$ (Bovin Serum Albumin) dan kertas saring. Alat yang digunakan adalah gunting, pisau, baskom, ember, GPS, pH meter, termometer suhu, tali rafia, mistar, kamera digital, alat tulis menulis, timbangan analitik, timbangan digital, gelas ukur, tabung reaksi, erlenmeyer, pipet volume, oven, blender, desikator, dan biuret.

Prosedur pelaksanaan penelitian pada tahapan uji lapangan dan laboratorium, yaitu sebagai berikut:

\section{Uji Lapangan.}

a. Pemilihan sampel tanaman kakao dilakukan sebelum puncak panen yakni minimal satu bulan sebelum puncak panen dengan memberi label secara acak pada tanaman kakao jenis hibrida (Trinitario) warna hijau umur 8, 10, 12, dan 14 tahun.

Tabel 1. Rekapitulasi sidik ragam pengaruh letak buah kakao pada berbagai umur tanaman terhadap kualitas buah dan biji kakao

\begin{tabular}{llcc}
\hline \multirow{2}{*}{ No. } & \multicolumn{2}{c}{ Variabel Pengamatan } & \multicolumn{2}{c}{ Uji F } \\
\cline { 3 - 4 } & & Umur & Letak Buah \\
\hline 1. & Panjang Buah & $* *$ & $* *$ \\
2. & Lilit Buah & tn & $* *$ \\
3. & Berat Buah & $* *$ & $* *$ \\
4. & Jumlah Biji & $* *$ & $* *$ \\
5. & Berat Basah Biji & Keterangan: $* *=$ Berpengaruh sangat nyata dan tn $=$ Berpengaruh tidak nyata
\end{tabular}

Tabel 1 menunjukkan bahwa hasil sidik ragam untuk faktor umur tanaman kakao berpengaruh sangat nyata terhadap semua variabel penelitian kecuali berat buah. b. Tanaman kakao yang diberi label secara acak untuk masing-masing umur $8,10,12$ dan 14 tahun sebanyak 3 tanaman, sehingga jumlah tanaman kakao yang diberi label sebanyak 36 tanaman. Pemberian label untuk buah kakao dilakukan secara berurutan sesuai letak masingmasing buah pada tanaman kakao yaitu pada batang, cabang primer dan cabang sekunder.

c. Buah kakao yang diberi label secara berurutan sebanyak 3 buah pada setiap batang, cabang primer dan cabang sekunder, sehingga jumlah buah kakao yang diberi label pada tiap tanaman kakao sebanyak 9 buah. Total buah kakao yang diberi label pada semua sampel tanaman kakao sebanyak 108 buah.

Rancangan percobaan yang digunakan dalam penelitian ini adalah rancangan tersarang dengan pola RAL dengan 3 ulangan. Umur tanaman yaitu tanaman kakao umur 8, 10, 12 dan 14 tahun; serta letak buah tersarang pada umur tanaman meliputi batang, cabang primer dan cabang sekunder. Setiap plot terdiri dari 3 unit percobaan dan setiap unit percobaan terdiri dari 3 tanaman sehingga jumlah tanaman menjadi 36 tanaman kakao dan 108 buah kakao.

Pengamatan dilakukan terhadap peubah panjang buah, lilit buah, berat buah, jumlah biji dan berat basah biji.

Data hasil pengamatan yang diperoleh meliputi kualitas fisik dan kimia biji kakao dianalisis dengan sidik ragam. Jika hasil sidik ragam ada beda nyata diteruskan dengan Uji Jarak Berganda Duncan taraf 5\%.

\section{HASIL DAN PEMBAHASAN}

\section{Hasil Pengamatan}

Rekapitulasi hasil sidik ragam pengaruh letak buah kakao pada berbagai umur tanaman terhadap kualitas buah dan biji kakao disajikan pada Tabel 1 .

\section{Panjang Buah, Lilit Buah, Berat Basah Buah}

Hasil pengamatan terhadap rata-rata panjang buah, lilit buah dan berat buah berdasarkan letak buah kakao pada berbagai umur tanaman 
disajikan pada Gambar 1a, 1b dan 1c. Hasil uji UJBD pengaruh umur dan letak buah terhadap panjang buah, lilit buah dan berat buah kakao disajikan pada Tabel 2 .

Tabel 2. $\quad$ Rata-rata panjang buah $(\mathrm{cm})$, lilit buah $(\mathrm{cm})$ dan berat buah $(\mathrm{g})$ berdasarkan letak buah kakao pada berbagai umur tanaman

\begin{tabular}{|c|c|c|c|c|c|c|}
\hline \multirow{2}{*}{ Umur Tanaman } & \multicolumn{6}{|c|}{ Letak Buah } \\
\hline & $\mathrm{T}$ & & $\mathrm{P}$ & & & $S$ \\
\hline \multicolumn{7}{|c|}{ Panjang Buah (cm) } \\
\hline 8 Tahun & $20.62 \mathrm{~A}$ & & $19.83 \mathrm{~b}$ & & 18.99 & $\mathrm{c}$ \\
\hline 10 Tahun & $16.86 \mathrm{D}$ & & $16.22 \mathrm{e}$ & & 15.28 & $\mathrm{f}$ \\
\hline 12 Tahun & $14.52 \mathrm{G}$ & & $13.97 \mathrm{~h}$ & & 13.23 & $\mathrm{ij}$ \\
\hline 14 Tahun & $13.50 \quad \mathrm{I}$ & & $12.78 \mathrm{j}$ & & 11.87 & $\mathrm{k}$ \\
\hline \multicolumn{7}{|c|}{ Lilit Buah (cm) } \\
\hline 8 Tahun & $33.30 \quad \mathrm{a}$ & a & $29.44 \quad b$ & & 27.86 & $\mathrm{c}$ \\
\hline 10 Tahun & $29.46 \quad b$ & $b$ & $27.08 \mathrm{c}$ & & 25.92 & $\mathrm{~d}$ \\
\hline 12 Tahun & $27.01 \mathrm{c}$ & $c$ & $25.67 \mathrm{~d}$ & & 25.35 & $\mathrm{~d}$ \\
\hline 14 Tahun & $25.93 \mathrm{~d}$ & $d$ & $25.64 \mathrm{~d}$ & & 25.31 & $\mathrm{~d}$ \\
\hline \multicolumn{7}{|c|}{ Berat Buah $(\mathrm{g})$} \\
\hline 8 Tahun & 487.72 & $\mathrm{a}$ & 438.72 & $a b c$ & 380.7 & 39 bcd \\
\hline 10 Tahun & 495.50 & $\mathrm{a}$ & 421.17 & abcd & 360. & 78 bcd \\
\hline 12 Tahun & 456.17 & $a b$ & 405.33 & abcd & 344. & $67 \mathrm{~cd}$ \\
\hline 14 Tahun & 422.78 & abcd & 365.11 & bcd & 326.8 & $33 \mathrm{~d}$ \\
\hline
\end{tabular}

Keterangan: T (batang), P (cabang primer) dan S (cabang sekunder). Angka-angka yang diikuti oleh huruf yang sama pada kolom yang sama menunjukkan berbeda tidak nyata pada UJBD $\alpha=0.05$.

Tabel 2 menunjukkan bahwa panjang buah kakao terpanjang diperoleh pada umur 8 tahun pada batang utama yang berbeda nyata dengan panjang buah kakao pada umur 10, 12 dan 14 tahun baik itu pada cabang primer dan cabang sekunder. Pengaruh letak buah terhadap lilit buah kakao tertinggi diperoleh pada umur 8 tahun pada batang utama yang berbeda nyata dengan lilit buah kakao pada umur 10, 12 dan 14 tahun pada letak buah pada cabang primer dan cabang sekunder. Pengaruh letak buah terhadap berat buah kakao tertinggi diperoleh pada umur 10 tahun pada batang utama yang berbeda tidak nyata dengan lilit buah kakao pada umur 8, 12 dan 14 tahun pada letak buah pada batang utama dan umur 8,10 dan 12 tahun pada cabang primer, tetapi berbeda nyata dengan berat buah kakao pada umur 14 tahun pada letak buah cabang primer dan umur $8,10,12$ dan 14 tahun pada cabang sekunder.

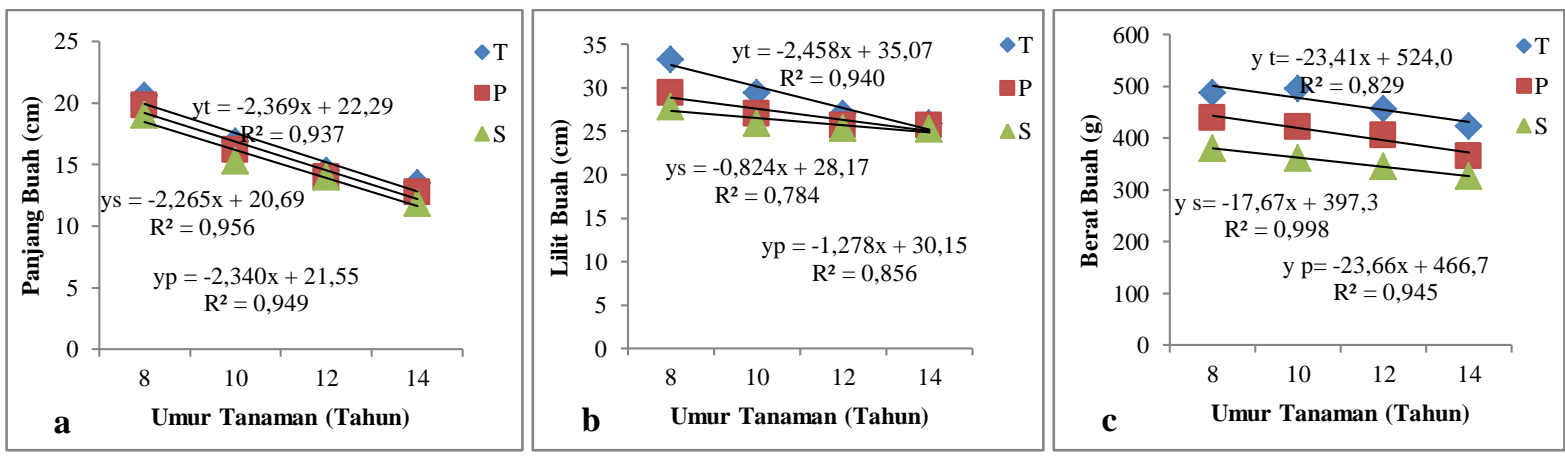

Gambar 1. Hubungan letak buah dengan umur tanaman terhadap panjang buah kakao (a) lilit buah (b) dan berat buah (c). Keterangan: yt (panjang buah pada batang utama), yp (panjang buah pada cabang primer), ys (panjang buah pada cabang sekunder).

Gambar 1a menunjukkan bahwa rata-rata panjang buah kakao menurun seiring dengan lama umur tanaman kakao. Rata-rata panjang buah kakao tertinggi diperoleh pada umur tanaman 8 tahun dan terendah pada umur tanaman kakao 14 tahun. Panjang buah kakao tertinggi diperoleh pada cabang primer dan terendah pada cabang sekunder. Hasil analisis regresi panjang buah terhadap umur 
tanaman pada berbagai posisi letak buah disajikan pada Gambar 1a. Gambar 1b menunjukkan bahwa rata-rata lilit buah kakao menurun seiring dengan lama umur tanaman kakao, artinya semakin tua tanaman maka menghasilkan lilit buah yang relatif lebih kecil. Rata-rata lilit buah kakao tertinggi diperoleh pada umur tanaman 8 tahun dan terendah pada umur tanaman kakao 14 tahun. Letak buah kakao tertinggi diperoleh pada batang utama dan terendah pada cabang sekunder. Nilai analisis regresi antara lilit buah dengan umur tanaman untuk berbagai posisi letak buah disajikan pada Gambar 1b. Hasil penelitian terhadap letak buah kakao pada berbagai umur tanaman pada Gambar 1c menunjukkan bahwa rata-rata berat buah kakao menurun seiring dengan lama umur tanaman kakao. Rata-rata berat buah kakao tertinggi diperoleh pada umur tanaman 10 tahun pada letak buah batang utama dan rata-rata berat buah tertinggi pada cabang primer dan cabang sekunder diperoleh pada umur 8 tahun dan terendah pada umur tanaman kakao 14 tahun. Hasil analisis regresi berat buah kakao terhadap umur tanaman pada berbagai posisi letak buah disajikan pada Gambar 1c.

\section{Jumlah Biji dan Berat Basah Biji}

Hasil pengamatan terhadap rata-rata jumlah biji buah kakao berdasarkan letak buah kakao pada berbagai umur tanaman disajikan pada Gambar 2a, 2b dan 2c. Hasil uji UJBD pengaruh umur dan letak buah kakao terhadap jumlah biji kakao disajikan pada Tabel 3.

Tabel 3 menunjukkan bahwa pengaruh letak buah terhadap jumlah biji buah kakao tertinggi diperoleh pada umur 8 tahun pada batang utama yang berbeda nyata dengan jumlah biji buah kakao pada umur 10, 12 dan 14 tahun pada letak buah pada cabang primer dan cabang sekunder. Pengaruh letak buah terhadap berat basah biji kakao tertinggi diperoleh pada umur 8 tahun pada batang utama yang berbeda nyata dengan berat basah biji kakao pada umur 10, 12 dan 14 tahun pada letak buah pada cabang primer dan cabang sekunder. Pengaruh letak buah terhadap bobot kering keping biji tertinggi diperoleh pada umur 8 tahun pada batang utama yang berbeda nyata dengan berat basah biji kakao pada umur 10, 12 dan 14 tahun pada letak buah pada cabang primer dan cabang sekunder.

Gambar 2a menunjukkan bahwa umur tanaman mempengaruhi jumlah biji buah kakao. Rata-rata jumlah biji tertinggi diperoleh pada umur 8 tahun dan terendah pada umur 14 tahun. Letak buah terhadap jumlah biji buah tertinggi pada umur 8 tahun diperoleh pada batang utama dan terendah pada cabang sekunder. Nilai analisis regresi antara jumlah biji dengan umur tanaman untuk berbagai posisi letak buah disajikan pada Gambar 2a. Gambar 2b menunjukkan bahwa ratarata berat basah biji kakao menurun seiring dengan lama umur tanaman kakao. Rata-rata berat basah biji buah kakao tertinggi diperoleh pada umur tanaman 8 tahun dan terendah pada umur tanaman 14 tahun. Letak buah kakao tertinggi diperoleh pada batang utama dan terendah pada cabang sekunder. Hasil analisis regresi berat basah biji kakao terhadap umur tanaman pada berbagai posisi letak buah disajikan pada Gambar $2 b$.

Tabel 3. Rata-rata jumlah biji kakao (biji/buah) berdasarkan letak buah kakao pada berbagai umur tanaman

\begin{tabular}{|c|c|c|c|c|c|c|}
\hline \multirow{2}{*}{ Umur Tanaman } & \multicolumn{6}{|c|}{ Letak Buah } \\
\hline & & $\mathrm{T}$ & & $\mathrm{P}$ & & $\mathrm{S}$ \\
\hline \multicolumn{7}{|c|}{ Jumlah Biji } \\
\hline 8 Tahun & 43.00 & $\mathrm{a}$ & 37.22 & $\mathrm{~b}$ & 32.72 & $\mathrm{~d}$ \\
\hline 10 Tahun & 35.86 & $\mathrm{c}$ & 31.08 & $\mathrm{e}$ & 28.19 & $\mathrm{f}$ \\
\hline 12 Tahun & 30.23 & $\mathrm{e}$ & 27.90 & $\mathrm{f}$ & 26.23 & $\mathrm{~g}$ \\
\hline 14 Tahun & 28.00 & $\mathrm{f}$ & 26.33 & $\mathrm{~g}$ & 25.28 & $\mathrm{~g}$ \\
\hline \multicolumn{7}{|c|}{ Berat Basah Biji $(\mathrm{g})$} \\
\hline 8 Tahun & 185.99 & $\mathrm{a}$ & 182.63 & $\mathrm{~b}$ & 178.61 & $\mathrm{~d}$ \\
\hline 10 Tahun & 181.14 & $\mathrm{c}$ & 178.56 & $\mathrm{~d}$ & 176.15 & $\mathrm{e}$ \\
\hline 12 Tahun & 175.91 & $\mathrm{e}$ & 173.56 & $f$ & 171.37 & $\mathrm{~g}$ \\
\hline 14 Tahun & 170.97 & $\mathrm{~g}$ & 167.79 & $\mathrm{~h}$ & 164.91 & $i$ \\
\hline
\end{tabular}

Keterangan: T (batang), P (cabang primer) dan S (cabang sekunder). Angka-angka yang diikuti oleh huruf yang sama pada kolom yang sama menunjukkan berbeda tidak nyata pada UJBD $\alpha=0.05$ 

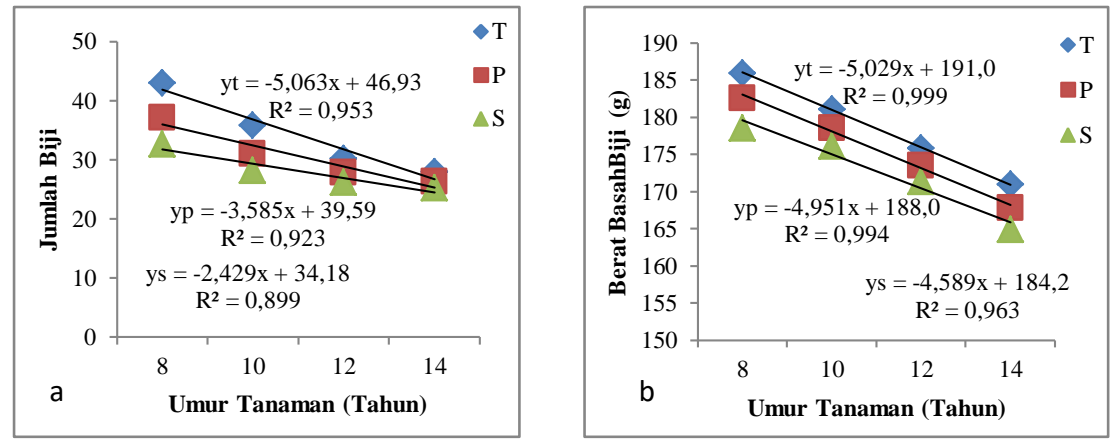

Gambar 2. Hubungan letak buah dengan umur tanaman terhadap jumlah biji (a) dan berat basah biji (b). Keterangan: yt (jumlah biji pada batang utama), yp (jumlah biji pada cabang primer), ys (jumlah biji pada cabang sekunder).

\section{PEMBAHASAN}

Hasil penelitian menunjukkan bahwa pengaruh letak buah kakao dan umur tanaman berpengaruh secara signifikan terhadap kualitas buah dan biji kakao. Hasil penelitian menunjukkan bahwa umur tanaman berpengaruh sangat nyata terhadap semua variabel penelitian kecuali pada variabel berat buah berpengaruh tidak nyata. Hal ini mengindikasikan bahwa mutu buah dan biji kakao lebih banyak dipengaruhi oleh umur kakao bila dibandingkan dengan letak buah kakao. Menurut Spillane (1995) dan Rubiyo \& Siswanto (2012), bahwa pohon kakao mencapai tingkat produksi maksimum sesudah enam atau tujuh tahun dan mulai berbuah sesudah tiga tahun. Pohon terus menerus berbuah selama beberapa tahun, tetapi pada umumnya hasil mulai turun saat tanaman mulai tua atau lebih awal jika pohon tidak dipelihara dengan baik atau mengalami penyakit.

Hasil penelitian terhadap beberapa variabel panjang buah kakao menunjukkan bahwa umur tanaman 8 tahun memberikan hasil terbaik terhadap panjang buah (Gambar 1a). Hal ini diduga bahwa umur tanaman 8 tahun merupakan umur produktif tanaman kakao, sehingga kemampuan penyerapan hara lebih maksimal bila dibandingkan dengan umur tanaman tua. Zaenudin dan Baon (2004), melaporkan bahwa tanaman kakao produktivitas tanaman lebih besar saat tanaman berusia produktif yaitu sekitar 5-10 tahun selanjutnya produktivitas tanaman menurun seiring dengan semakin tua umur tanaman. Tanaman tersebut umumnya memiliki produktivitas yang hanya tinggal setengah dari potensi produktivitasnya. Kondisi ini berarti bahwa tanaman kakao yang sudah tua potensi produktivitasnya rendah.

Selain panjang buah, secara umum hasil penelitian menunjukkan umur tanaman kakao berpengaruh sangat nyata terhadap kualitas biji kakao. Hasil penelitian terhadap variabel pengamatan (lilit buah, berat buah, jumlah biji dan berat basah sangat dipengaruhi oleh umur tanaman dan letak buah.

Secara umum umur tanaman 8 tahun merupakan hasil terbaik terhadap kualitas buah dan biji kakao. Hal ini diduga bahwa kemampuan tanaman untuk memanfaatkan unsur hara dalam tanah lebih maksimal. Hal ini selanjutnya berdampak terhadap kualitas buah dan biji kakao. Umur tanaman kakao sangat mempengaruhi kualitas buah dan biji kakao. Secara umum tanaman umur 8 tahun memberikan hasil terbaik terhadap kualitas buah dan biji kakao. Hasil penelitian menunjukkan bahwa umur tanaman menurunkan kualitas buah dan biji kakao. Hal ini sejalan dengan penelitian Alam et al., (1997) yang melaporkan bahwa selama kurun waktu 12 tahun mutu biji kakao rakyat di Kabupaten ini mengalami penurunan kualitas buah kakao.

Hasil penelitian menunjukkan bahwa selain umur tanaman letak buah juga sangat dipengaruhi oleh letak buah kakao. Secara umum letak buah kakao pada batang utama memberikan hasil terbaik terhadap mutu buah dan kualitas biji kakao bila dibandingkan dengan letak buah pada cabang primer dan cabang sekunder. Hal ini diduga berkaitan dengan translokasi unsur hara pada tanaman bahwa pada cabang sekunder. Hal ini diduga berkaitan dengan hasil asimilasi tanaman yang ditranlokasikan dari daun. Hasil penelitian ini relevan dengan penelitian Jurniati (2013), menunjukkan bahwa berat daging buah kakao pada batang rata-rata $407,311 \mathrm{~g} /$ buah lebih tinggi dari buah pada cabang rata-rata $383,873 \mathrm{~g} /$ buah. Berat plasenta buah pada batang 15,662 g/buah lebih tinggi dari buah pada cabang rata-rata 13,902 $\mathrm{g} / \mathrm{buah}$. Berat biji dengan pulp buah pada batang rata-rata 93,893 lebih tinggi dari buah pada cabang rata-rata 87,377 . Berat biji tanpa pulp buah pada batang rata-rata $66,371 \mathrm{~g} /$ buah lebih tinggi dari buah pada cabang rata-rata 62,187 . Jumlah biji per buah 
pada batang rata-rata $42,0 \mathrm{biji} / \mathrm{buah}$ lebih tinggi dari buah pada cabang rata-rata 40,5 biji/buah. Kadar air biji pada batang rata-rata $6,42 \%$ lebih tinggi dari buah pada cabang $6,39 \%$.

\section{KESIMPULAN}

Letak buah kakao mempengaruhi variabel pengamatan kecuali pada kadar protein dan kadar lemak. Mutu kakao terbaik terletak pada batang utamanya. Semakin tua tanaman kakao maka semakin menurun mutu kakaonya. Mutu kakao terbaik antara 8, 10, 12 dan 14 tahun yaitu pada umur 8 tahun.

\section{DAFTAR PUSTAKA}

BPS, 2014. Kecamatan Wonggeduku dalam Angka 2014. Badan Pusat Statistik Kabupaten Konawe.

Departemen Perindustrian, 2007. Gambaran Sekilas Industri Kakao, Jakarta.

Fahmi, Z.I. 2011. Penggunaan Benih Kakao Bermutu dan Tehnik Budidaya. Balai Besar Perbenihan dan Proteksi Tanaman Perkebunan, Surabaya.

FAO. 2007. Theobroma cacao. Food and Agriculture Organization of the U.N. Available at: http://ecocrop.fao.org/ecocrop/sru/en/cropVie $\mathrm{w}$ ?id=2074 (diakses tanggal 5-11-2015).

Laporan Lokakarya Kakao Indonesia, 2013. Cokelatku Budayaku Indonesiaku. Laporan Lokakarya Kakao Indonesia, 18 September 2013.

Spillane, J. 1995. Komoditi Kakao, Peranannya dalam Perekonomian Indonesia. Kanisius. Yogyakarta.

Supriatna, A. 2004. Kinerja Usahatani kakao Rakyat Sebelum dan Sesudah Krisis Ekonomi (Studi Kasus di Provinsi Sulawesi Selatan), Icaserd Working Paper 44, Pusat Penelitian dan 